\title{
Szemléletváltozás az alsó végtagi érrekonstrukciók gyakorlatában a Szegedi Tudományegyetem Érsebészeti Osztályán
}

\author{
Takács Tibor dr. ${ }^{1}$ - Mihalovits Gábor dr. ${ }^{1}$ - Váradi Rita dr. ${ }^{1}$ \\ Nagy András dr. ${ }^{2}$. Nagy Endre dr. ${ }^{2}$. Palásthy Zsolt dr. ${ }^{1}$
}

\author{
Szegedi Tudományegyetem, Általános Orvostudományi Kar, Szent-Györgyi Albert Klinikai Központ, \\ Sebészeti Klinika, Szeged, \\ ${ }^{2}$ Szegedi Tudományegyetem, Általános Orvostudományi Kar, Szent-Györgyi Albert Klinikai Központ, \\ Radiológiai Klinika, Szeged
}

\begin{abstract}
Bevezetés: Az endovascularis intervenciókat kezdetben radiológusok alkalmazták, manapság, megfelelő képzést követően, jó eredménnyel végeznek ilyen beavatkozásokat érsebészek is. Ezt a világszerte uralkodóvá váló szemléletet kívántuk meghonosítani a Szegedi Tudományegyetemen, melynek bevezetése nélkül előrevetíthető az érsebészet múködésének átalakulása az érrekonstrukciós beavatkozások csökkenésével.

Célkitüzés: Egyetemünkön radiológus- és érsebész-munkacsoport végez perifériás érintervenciókat. Célunk a két intézet alsó végtagi endovascularis tevékenységének összehasonlítása volt.

Módszer: Vizsgálatunkba a Szegedi Tudományegyetemen 2012. 01. 01. és 2019. 12. 31. között alsó végtagi endovascularis beavatkozásokon átesett betegeket válogattuk be. A betegeket a rizikófaktoraik, a kezelt anatómiai régiók, a hospitalizációs idő és a szövődmények tekintetében hasonlítottuk össze. Egyéves utánkövetés során vizsgáltuk a 'redo' mútétek , az amputációk és a halálozások gyakoriságát.

Eredmények: A beavatkozásokat 653 esetben radiológus, 573 esetben érsebész végezte. Az érmútőben infrainguinalis $(63,2 \%)$, a radiológián suprainguinalis érintervenciók $(68,6 \%)$ történtek nagyobb arányban. A percutan végzett beavatkozásokat vizsgálva a hospitalizációs időben $(2,5 \pm 4,4$ nap vs. $2,4 \pm 2,5$ nap, $\mathrm{p}=0,78)$, valamint a minimálisan invazív módon végzett beavatkozások utáni szövődmények gyakoriságában (30/653 - 4,6\% és 11/257 - 4,3\%, $\mathrm{p}=0,837)$ nem volt különbség a két betegcsoport között. 'Redo' mútétek $(73 / 485-15,1 \%$ és 33/562 - 5,9\%, $\mathrm{p}<0,001)$ és amputációk $(31 / 485-6,4 \%$ és $12 / 562-2,1 \%, \mathrm{p}<0,001)$ gyakrabban fordultak elő az érmútóben kezelt betegek körében, ebben a csoportban azonban a kritikus végtagischaemia előfordulása is gyakoribb volt ( $45,4 \%$ és $38,6 \%, \mathrm{p}=0,016)$. A mortalitásban nem volt szignifikáns különbség $(5,8 \%$ és 3,9\%, p = 0,16).

Következtetés: A szoliter érelváltozások kezelését mindkét intézet hasonló hatásfokkal végezte. A több anatómiai régiót érintő betegség miatt érmútőben végzett beavatkozások utáni szövődmények előfordulása kissé magasabbnak bizonyult.
\end{abstract}

Orv Hetil. 2021; 162(24): 943-951.

Kulcsszavak: perifériás érbetegség, endovascularis kezelés, minimálisan invazív

Paradigm shift in the vascular surgery of the lower extremity at the Department of Vascular Surgery, University of Szeged, Hungary

Introduction: Endovascular interventions were initially performed by radiologists. Nowadays properly trained vascular surgeons also effectively perform these interventions. We wished to apply this widespread practice at our university because without this advancement the number of reconstructive surgeries was expected to decrease significantly. Objective: Both radiologists and vascular surgeons perform endovascular interventions at our university. We compared the outcomes of lower extremity endovascular interventions between the two institutes. 
Method: We included patients who underwent lower extremity endovascular interventions between 01. 01.2012 and 31. 12. 2019. We compared the risk factors, treated anatomical regions, hospitalization time and complication rate. During the one-year follow-up, we examined the occurrence of redo surgeries, amputations and mortality.

Results: 653 interventions were performed by radiologists and 573 by vascular surgeons. Vascular surgeons carried out more interventions in the infrainguinal region $(63.2 \%)$, while radiologists in the suprainguinal region $(68.6 \%)$. The hospitalization time after percutaneous interventions $(2.5 \pm 4.4$ days vs. $2.4 \pm 2.5$ days, $\mathrm{p}=0.78)$, and the rate of complications after minimally invasive interventions did not show significant difference $(30 / 653-4.6 \%$ vs. $11 / 257-4.3 \%, \mathrm{p}=0.837)$. Redo surgeries $(73 / 485-15.1 \%$ vs. $33 / 562-5.9 \%, \mathrm{p}<0.001)$ and amputations $(31 / 485-6.4 \%$ vs. $12 / 562-2.1 \%, \mathrm{p}<0.001)$ occurred more frequently in the surgical group. However, the incidence of chronic limb ischaemia was also higher $(45.4 \%$ vs. $38.6 \%, \mathrm{p}=0.016)$. There was no significant difference in the mortality $(5.8 \%$ vs. $3.9 \%, \mathrm{p}=0.16)$.

Conclusion: Both institutes had similar efficacy in performing peripheral interventions on solitary vascular lesions. Complications occurred more frequently in the surgical group, but the majority of these patients had extended atherosclerotic diseases.

Keywords: peripheral arterial disease, endovascular treatment, minimally invasive

Takács T, Mihalovits G, Váradi R, Nagy A, Nagy E, Palásthy Zs. [Paradigm shift in the vascular surgery of the lower extremity at the Department of Vascular Surgery, University of Szeged, Hungary]. Orv Hetil. 2021; 162(24): 943951.

(Beérkezett: 2020. november 2.; elfogadva: 2020. december 8.)

\section{Rövidítések}

CLTI $=$ (chronic limb-threatening ischaemia) kritikus végtagischaemia; $\mathrm{CT}=$ (computed tomography) számítógépes tomográfia; ESVS = (European Society for Vascular Surgery $)$ Európai Érsebészeti Társaság; DEB = (drug-eluting balloon) gyógyszerkibocsátó ballon; DES = (drug-eluting stent) gyógyszerkibocsátó sztent; DSA = digitális szubtrakciós angiográfia; LMWH $=$ (low-molecular-weight heparin) kis molekulatömegú heparin; PTA = percutan transluminaris angioplastica; SZTE $=$ Szegedi Tudományegyetem; USA $=($ United States of America) Amerikai Egyesült Államok

$\mathrm{Az}$ alsó végtagi atheroscleroticus érbetegségek kezelési stratégiája az utóbbi évtizedekben számottevően megváltozott. Ennek egyik oka, hogy az alsó végtagi érbetegség következtében kialakuló intermittáló claudicatio (claudicatio intermittens) állapotában (Fontaine II. stádium) napjainkban már nem a hagyományos érsebészeti beavatkozások az első vonalbeli választandó módszerek. Jelentősen felértékelődött a járástréning terápiás szerepe, különösen annak kontrollált formában történő alkalmazása tekintetében. Ezekrôl a kezelésekról mára bebizonyosodott, hogy a járástávolság növelésén kívül számottevő, a cardiovascularis rizikót csökkentő hatással is bírnak [1-3]. A gyógyszeres terápia vonatkozásában a másodlagos prevenció kiterjedt eszköztára mellett a komplex hatású cilostazol - melyet elsőként 1986-ban Japánban engedélyeztettek - igazoltan növeli mind a fájdalommentes, mind az abszolút járástávolságot alsó végtagi érbetegség esetén, javítva ezzel az életminőséget is [4]. A gyógyszert Magyarországon majd' három évtizeddel késóbb, 2014-ben engedélyezték, mellyel a klinikai gyakorlatban ez a tendencia itthon is érezhetôvé vált $[5,6]$.
Az endovascularis intervenciók megjelenését követően az utóbbi évtizedekben az érrekonstrukciók jellege is megváltozott. Manapság már ezek az eljárások tekintendők az elsődlegesen választandó módszereknek a perifériás érbetegségek invazív kezelésében [7]. Kisebb megterhelést jelentenek a betegeknek, így sok esetben a nyitott mûtétre általános állapotuk, illetve kísérő betegségeik miatt nem alkalmas páciensek is eredményesen kezelhetôvé válnak, ugyanakkor a rekonstrukciók határai is kiterjeszthetők a korábban korlátozottan hozzáférhető cruralis megbetegedések egy részére is. A technika folyamatos fejlődése (gyógyszerkibocsátó eszközök - 'drugeluting balloon' [DEB], 'drug-eluting stent' [DES], perifériás sztentgraftok megjelenése) következtében azon irányelvek, melyek csak az elváltozások morfológiája alapján tettek javaslatot a perifériás verőérbetegségek kezelésének módszerére, mára részben elavulttá is váltak $[8,9]$. Bár a minimálisan invazív eljárások költségvonzata igen magas lehet, a megfelelő finanszírozási háttérnek köszönhetően a fejlett nyugati országokban a nyitott érsebészeti mútétek jelentősen háttérbe szorultak az érrekonstrukciós beavatkozások között [10, 11]. Erre a tendenciára a nemzetközi szakirodalom is felfigyelt, számos publikáció foglalkozik az érsebészet jövőjével. A perifériás érbetegek kezelésében az érsebészet fokozatosan elveszítheti a múltban meglévő vezetô szerepét, amennyiben nem képes alkalmazkodni a modern egészségügy kihívásaihoz. A folyamatban jóval előttünk járó Egyesült Államokban a kérdést gondolatébresztő módon a következőképpen fogalmazták meg: „Az érsebészet jövője, lehetôség vagy nekrológ?” (Yorkovich WR, Ascher E. Division of Vascular Surgery, Brooklyn, NY, USA). A XXI. század érsebészeinek multiplex technikák alkalmazása révén képesnek kell lenniük a gyakran kihívást jelen- 
tő anatómiai viszonyok rekonstrukciójára, lehetőleg a beteg számára kevésbé megterhelő és esztétikailag is elönyös módon, mindeközben lépést tartva a folyamatos innovációval is [12]. Frank J. Veith, a világ érsebész-társadalmának meghatározó egyénisége, aki az USA-ban elsőként végzett aortasztentgraft-beültetést, már 2016ban azt prognosztizálta, hogy a nem túl távoli jövőben - 2026-ra - az érrekonstrukciók 70-95\%-át endovascularis módszerekkel fogják végezni [13].

A fentiek következtében a katéteres beavatkozások jelentős részét nyugaton napjainkra már érsebészek végzik. Magyarországon a helyzet sajnos ettől még messze elmarad. A percutan endovascularis módszerek döntően az intervenciós radiológusok és az invazív kardiológusok kezében vannak, az érsebészet ezen beavatkozásokhoz jobbára csak osztályos hátteret biztosít. Nyitott érsebészeti mútétre egyre inkább csak az endovascularisan nem megoldható esetekben vagy akut indikációval, illetve a posztintervenciós szövődmények ellátásakor kerül sor. Néhány hazai érsebészeti centrumban azonban az utóbbi időben egyre nagyobb számú katéteres beavatkozást végeznek érmútőben, gyakran kombinálva azokat nyitott technikákkal. Az ilyen, ún. hibrid mưtétek lehetővé teszik, hogy a több anatómiai régiót érintő - emeletes érbetegségek esetében, egy ülésben, kompromisszumok nélküli rekonstrukciót végezhessünk az invazivitás növelése nélkül. A módszer előnye, hogy hemodinamikailag kedvezőbb helyzetet teremtve javíthatja a nyitva maradást, továbbá az, hogy nem szükséges a betegeket kitenni a többszöri beavatkozás traumáinak. Ennek szellemében osztályunk gyakorlatában is szemléletváltás történt. A Szegedi Tudományegyetemen (SZTE) az intervenciós radiológiai, valamint az érsebészeti munkacsoport végez perifériás intervenciókat. Mütőnkben 2012 óta végzünk katéteres beavatkozásokat; ezt egy évig tartó betanulási fázis előzte meg, melynek során radiológusok felügyelték tevékenységünket.

\section{Célkitüzés}

Vizsgálatunk célja saját - érsebészeti endovascularis - tevékenységünk megítélése végett a két munkacsoport alsó végtagi endovascularis módszerrel kezelt betegeinek retrospektív elemzése, illetve összehasonlítása volt. Az érbetegségek anatómiai lokalizációjára, a beavatkozások heterogenitására, valamint az érvényes ajánlásokra is tekintettel egy ilyen tanulmány randomizált kivitelezése lényegében nem lehetséges. Intervenciós aktivitásunk hatékonyságának megismerése mégis hasznos tanulságot adhat további teendőinket illetôen.

\section{Módszer}

Retrospektív tanulmányunkban a SZTE Sebészeti Klinikájának Érsebészeti Osztályán és a Radiológiai Klinikán 2012. január 1. és 2019. december 31. között végzett alsó végtagi endovascularis rekonstrukción átesett bete- geket vizsgáltuk. A tervezett beavatkozások előtt a betegeknél diagnosztikus hagyományos vagy CT-angiográfia történt. Vizsgálatunk során rögzítettük a betegek életkorát, rizikófaktorait (kísérő betegségek: ischaemiás szívbetegség, krónikus tüdő-, vesebetegségek - krónikus veseelégtelenség jelenléte -, hypertonia, diabetes, hyperlipidaemia, dohányzás). Az indikáció tekintetében a mútéteket claudicatio vagy kritikus végtagischaemia (chronic limb-threatening ischaemia - CLTI) miatt végeztük. Összehasonlítottuk a két intézetben történt beavatkozásokat a kezelt anatómiai régiók (suprainguinalis vagy infrainguinalis régió) és az intervenció módja (sztentelés vagy csak ballonos tágítás) szerint. A sztentbeültetés során a suprainguinalis régióban inkább a primer sztentelés módszerét, míg az infrainguinalis régióban az ún. provizórikus sztentelés módszerét alkalmaztuk; az utóbbi esetben a beavatkozás során az érintett érszakaszon először ballonos tágítást végeztünk, melyet intraoperatív angiográfia követett. Amennyiben nem sikerült jó morfológiai eredményt elérni (például residualis stenosis, 'flow-limited' dissectio), sztentelést is végeztünk. Az intervenciós radiológián a beavatkozásokat percutan módszerrel végezték, többnyire brachialis, ritkábban femoralis punkcióból. Az érsebészeti mútőben végzett beavatkozások többségét hibrid mútét keretében végeztük, kisebbrészt percutan módon; ennek sikertelensége (például a beteg alkata, anatómiai okok, súlyosan meszes artéria a punkciós helyen) vagy több anatómiai régió együttes kezelése esetén a beavatkozások kis femoralis feltárásból direkt artériapunkcióval történtek. Rögzítettük a hospitalizációs időt, illetve a posztoperatív szövődmények gyakoriságát; utóbbiként definiáltunk minden olyan kórállapotot, mely a beavatkozással összefüggésbe hozhatóan 30 napon belül alakult ki, és kórházi/mútéti kezelést tett szükségessé. Azon betegeknél, akiknél a fizikális és a kézi Doppler-vizsgálat egyértelmű reocclusiót igazolt, vagy annak gyanúját vetette fel, artériás duplex ultrahangvizsgálat történt, melyet szükség esetén CTvagy hagyományos angiográfiával is kiegészítettünk a revascularisatiós lehetőségek megítélésére. A 2012. 01. 01. és 2018. 12. 31. között végzett beavatkozások esetén az egyéves utánkövetés eredményeit értékeltük. Megvizsgáltuk a 'redo', a kiegészítő mútétek, a major amputációk gyakoriságát, illetve a halálozást. 'Redo' mütétként definiáltunk minden olyan érsebészeti vagy intervenciós beavatkozást, melyet a primeren endovascularisan kezelt érszakaszon kellett ismételten végezni annak reocclusiója, restenosisa vagy egyéb szövődmény miatt. Kiegészítő mütétként definiáltunk minden olyan érsebészeti vagy intervenciós beavatkozást, melyet ugyanazon a végtagon, de a primeren endovascularisan kezelt érszakasztól eltérő lokalizációban kellett elvégezni. Major amputációként határoztuk meg a cruralis és a femoralis szintú amputációkat, illetve a csípőízületi exarticulatiót. Betegeinknél a beavatkozást követően kettős thrombocytaaggregáció-gátló terápiát alkalmaztunk legalább 3 hónapon át (az alapbetegségektől függően akár hosszabb távon), 
valamint a beavatkozás típusától, a beteg állapotától, illetve kísérő betegségeitől is függően legfeljebb 30 napig LMWH-thrombosisprofilaxist írtunk elő.

Statisztikai elemzéseink során a folyamatos változók összehasonlítását Student-féle t-teszttel, míg a kategorikus változók összehasonlítását khi-négyzet-próbával végeztük. Statisztikailag szignifikáns különbségnek a $\mathrm{p}<0,05$ értéket tekintettük.

Vizsgálatunkat a személyes adatok védelméról és a közérdekű adatok nyilvánosságáról szóló hatályos törvények figyelembevételével a SZTE Etikai Bizottsága által rendelkezésünkre bocsátott, 17/2018-SZTE és 122/2018-SZTE számú etikai engedélyek birtokában végeztük.

\section{Eredmények}

A vizsgált időszakban a SZTE-n összesen 1226 perifériás intervenció történt, melyek közül 653-at (653/1226 $53,3 \%)$ az intervenciós radiológiai, míg 573-at (573/1226 - 46,7\%) az érsebészeti munkacsoportunk végzett. Évekre lebontva látható, hogy 2015-ig nagyobb arányban történt perifériás endovascularis beavatkozás az intervenciós radiológián; ez az arány 2016-ban megfordult, majd 2018-tól kiegyenlítődött (1. ábra).

A rizikófaktorokat tekintve az intervenciós radiológián kezelt betegeknél az ischaemiás szívbetegség és a hyperlipidaemia nagyobb arányban fordult elő (1. táblázat).

$\mathrm{Az}$ indikáció tekintetében a CLTI miatt végzett beavatkozások az érmútőben kezelt betegek körében nagyobb arányban fordultak elő (2. ábra).

Évenkénti lebontásban látható, hogy a CLTI előfordulása, illetve ennek aránya a kezelt betegek között növekszik (3. ábra).

Az anatómiai lokalizáció tekintetében az infrainguinalis endovascularis rekonstrukciók az érműtőben, míg a
1. táblázat Rizikófaktorok a két intézetben alsó végtagi endovascularis be avatkozásokon átesett betegekben

\begin{tabular}{|c|c|c|c|c|c|}
\hline Rizikófaktorok & $\begin{array}{c}\text { Radiológia } \\
(\mathrm{n}=653)\end{array}$ & $\begin{array}{l}\text { Arány } \\
(\%)\end{array}$ & $\begin{array}{l}\text { Érsebészet } \\
(\mathrm{n}=573)\end{array}$ & $\begin{array}{c}\text { Arány } \\
(\%)\end{array}$ & p-érték \\
\hline $\begin{array}{l}\text { Ischaemiás } \\
\text { szívbetegség }\end{array}$ & 229 & 35,1 & 148 & 25,8 & 0,0005 \\
\hline $\begin{array}{l}\text { Krónikus } \\
\text { tüdőbetegség }\end{array}$ & 91 & 13,9 & 76 & 13,3 & 0,732 \\
\hline $\begin{array}{l}\text { Krónikus } \\
\text { veseelégtelenség }\end{array}$ & 55 & 8,4 & 37 & 6,5 & 0,193 \\
\hline Hypertonia & 559 & 85,6 & 471 & 82,2 & 0,105 \\
\hline Dohányzás & 559 & 85,6 & 491 & 85,7 & 0,966 \\
\hline Diabetes & 277 & 42,4 & 226 & 39,4 & 0,29 \\
\hline Hyperlipidaemia & 381 & 58,3 & 275 & 48 & 0,0003 \\
\hline $\begin{array}{l}\text { Életkor (év) } \\
\text { (átlag } \pm \text { szórás) }\end{array}$ & $65,2 \pm 9,2$ & & $65,3 \pm 9,4$ & & 0,851 \\
\hline
\end{tabular}

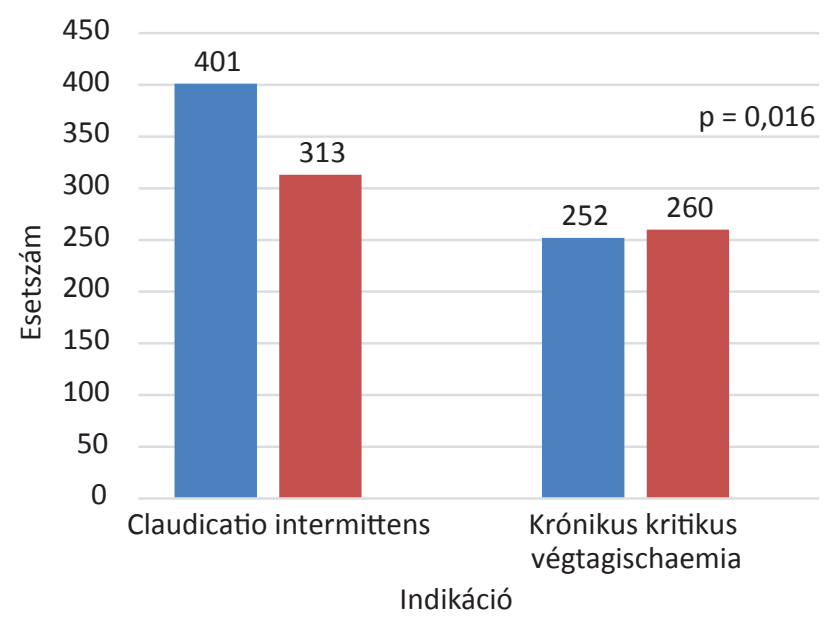

Radiológián végzett intervenciók

Érmútőben végzett intervenciók

2. ábra $\quad$ Az endovascularis beavatkozások indikációja az intervenciós ra diológián és az érmútốben kezelt betegeknél

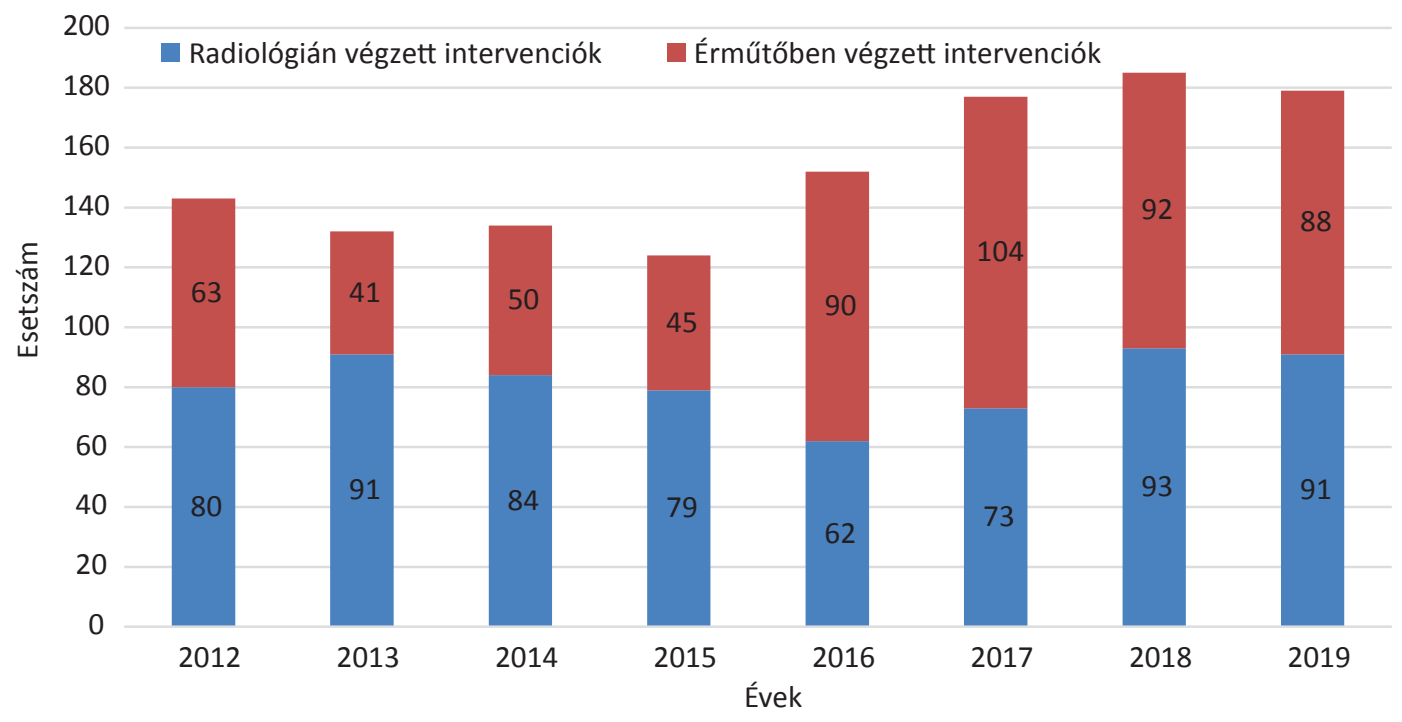

1. ábra Érmútóben és intervenciós radiológián végzett alsó végtagi endovascularis beavatkozások megoszlása 


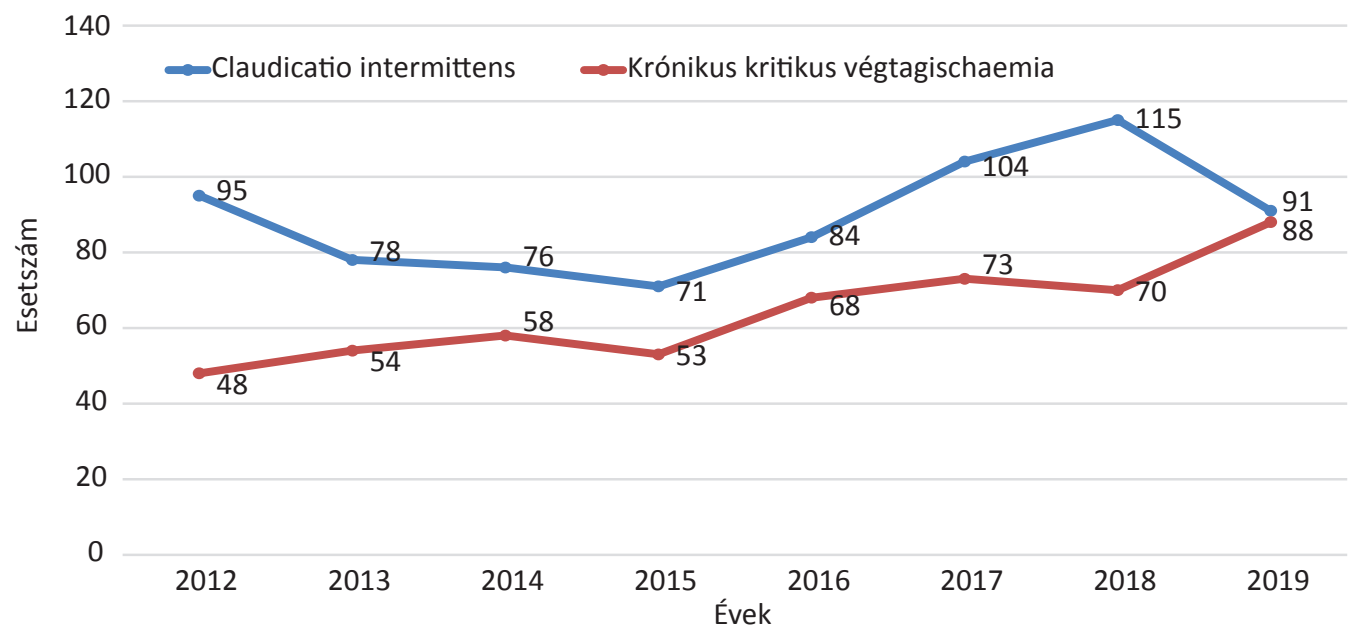

3. ábra | Az endovascularis beavatkozások indikációja 2012-2019 között

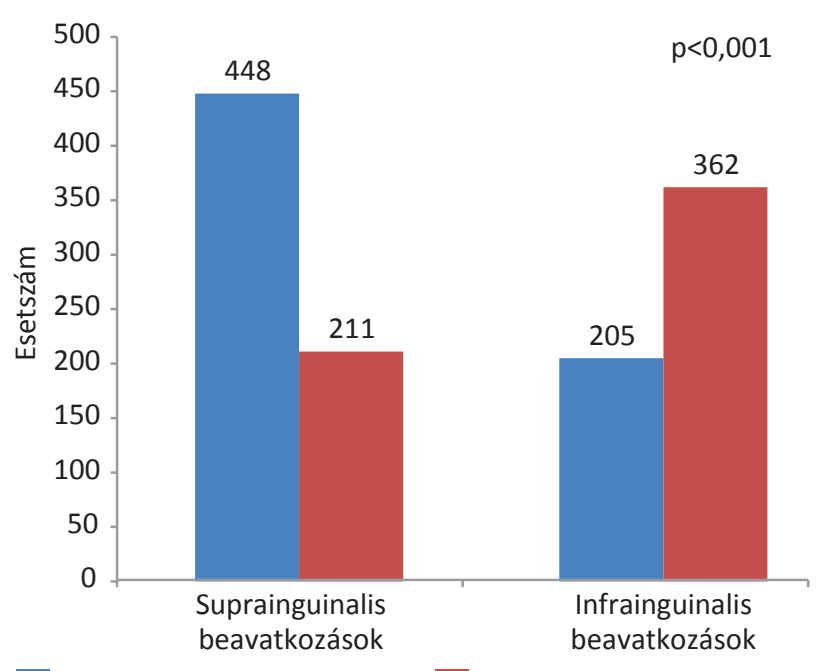

Radiológián kezelt betegek
Érmútőben kezelt betegek suprainguinalis beavatkozások az intervenciós radiológián történtek nagyobb arányban (4. ábra).

Fontos azonban kiemelni, hogy éles határt nem lehet húzni a kezelt anatómiai régiók között. Számos esetben előfordult, hogy egyszerre két anatómiai régiót kezeltünk: ilyen esetben azt a magasabb szintû régiót neveztük meg a lokalizációban, ahol endovascularis intervenciós beavatkozás történt.

A suprainguinalis intervenciók során mind az intervenciós radiológián, mind az érmútőben végzett esetekben a primer sztentelés volt gyakoribb. Az infrainguinalis intervenciók esetében az intervenciós radiológián a ballonos angioplasticát (percutan transluminaris angioplastica - PTA), míg az érmútóben végzett beavatkozásoknál a PTA/provizórikus sztentelés módszerét részesítettük előnyben (5. ábra).

A teljes beteganyagot vizsgálva az osztályunkon töltött posztintervenciós időszak rövidebb volt a radiológián végzett intervenciók esetén $(2,5 \pm 4,4$ nap vs. $6,2 \pm$

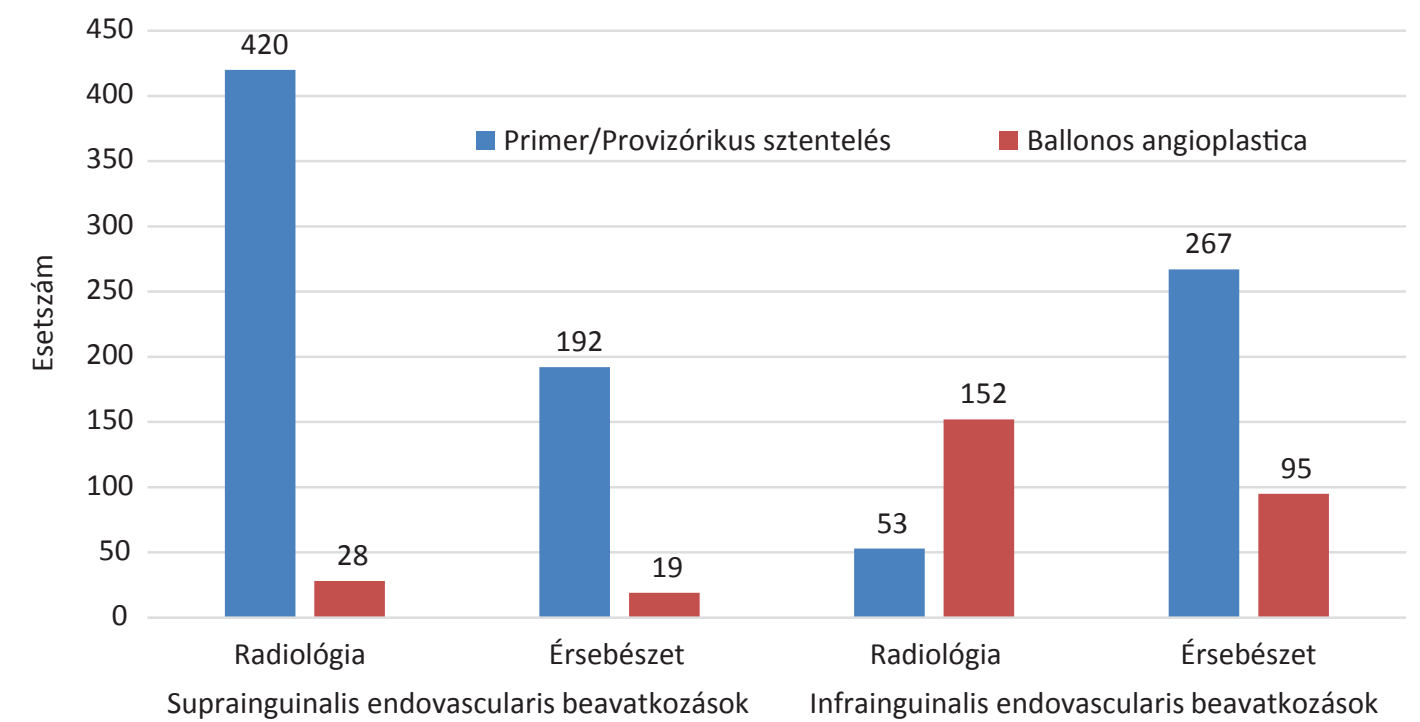

5. ábra | Sztentelés és a ballonos angioplastica használata az intervenciós radiológián és az érmútőben kezelt anatómiai régiókban 
4,1 nap, p<0,001). A csak percutan módszerrel kezelt eseteket vizsgálva (érmútőben ez 64 beteg) a különbség eltûnt $(2,5 \pm 4,4$ nap vs. $2,4 \pm 2,5$ nap, $\mathrm{p}=0,78)$.

Az érmütőben az endovascularis beavatkozásokat 316 esetben $(316 / 573-55,1 \%)$ hibrid mütétek keretében, míg 257 esetben $(257 / 573$ - 44,9\%) minimálisan invazív módon végeztük. A teljes beteganyagot vizsgálva a 30 napon belüli posztintervenciós szövődmények az érmútőben végzett beavatkozásokat követően összesen 45 esetben $(45 / 573-7,9 \%)$, míg az intervenciós radiológián kezelt betegek esetében 30 esetben $(30 / 653-4,6 \%)$ fordultak elő $(\mathrm{p}=0,018)$. A reoperációtól eltekintettünk a hibrid mútétek azon eseteiben, melyeknél csak a kezelt régiók egyike okkludált, ischaemiás jelek nem alakultak ki, és a végtag Doppler-indexe a beavatkozás előtti állapothoz képest javult. Amennyiben csak a minimálisan invazív módon, az érmútőben kezelt betegeket ( 257 beteg) hasonlítjuk össze a radiológián végzett beavatkozásokkal (653 beteg), a posztoperatív szövődmények előfordulásában a különbség már nem szignifikáns (11/257 - 4,3\% és 30/653 - 4,6\%, p = 0,837) (2. táblázat).

Hosszabb távú (egyéves) utánkövetést a 2012. 01. 01.-2018. 12. 31. között kezelt betegeknél végeztünk. A teljes beteganyagot vizsgálva 'redo' mütétekre gyakrabban volt szükség az érmütőben végzett beavatkozásokat követően $(73 / 485$ - 15,1\% és 33/562 - 5,9\%, $\mathrm{p}<0,001)$, és hasonlóan, a major amputációk aránya is nagyobb volt ebben a csoportban $(31 / 485-6,4 \%$ és $12 / 562-2,1 \%, \mathrm{p}<0,001)$. Amennyiben itt is, hasonlóan, csak a minimálisan invazív módon az érmútőben kezelt betegeket ( 219 beteg) hasonlítjuk össze a radiológián kezelt betegekkel (562 beteg), a 'redo' mútétek tekintetében a különbség még éppen szignifikáns volt $(22 / 219$ - 10\% és $33 / 562-5,9 \%, \mathrm{p}=0,041)$, a major amputációk tekintetében azonban a különbség már nem lett szignifikáns $(10 / 219-4,6 \%$ és $12 / 562-2,1 \%, \mathrm{p}=$ $0,065)$. Az egyéves mortalitásban a teljes beteganyagot vizsgálva nem volt szignifikáns különbség a két intézetben kezelt betegek között $(28 / 485$ - 5,8\% és $22 / 562$ $-3,9 \%, \mathrm{p}=0,16)$, s hasonlóan azon esetben sem, amikor a csak minimálisan invazív módon kezelt betegeket hasonlítottuk össze $(13 / 219$ - 5,9\% és 22/562 - 3,9\%, p = 0,22) (3. táblázat).

\section{Megbeszélés}

A perifériás intervenciók aránya az utóbbi időben növekszik, az endovascularis módszerek érsebészek által történő rutinszerü alkalmazásának terén hazánk azonban továbbra is lemaradással küzd. Egyetemünkön kitűnő, napi szintü, harmonikus kapcsolat alakult ki a perifériás érbetegek kezelését végző „vascularis team”-et alkotó

2. táblázat |Az alsó végtagi endovascularis beavatkozásokat követő 30 napon belüli szövődmények

\begin{tabular}{l|c|c|c|}
\hline \multirow{2}{*}{ Posztoperatív szövődmények } & \multicolumn{2}{|c|}{ Érsebészet } & Radiológia \\
\cline { 2 - 4 } & $\begin{array}{c}\text { Hibrid mütét } \\
316 \text { beteg }\end{array}$ & $\begin{array}{c}\text { Minimálisan invazív } \\
\text { beavatkozás } \\
257 \text { beteg }\end{array}$ & $\begin{array}{c}\text { Percutan intervenció } \\
653 \text { beteg * }\end{array}$ \\
\hline Amputáció & $5(1,6 \%)$ & $2(0,8 \%)$ & $7(1,1 \%)$ \\
\hline Összes reocclusio & $19(6 \%)$ & $2(0,8 \%)$ & $7(1,1 \%)$ \\
\hline Reoperáció/reintervenció reocclusio miatt & $15(4,7 \%)$ & $2(0,8 \%)$ & $7(1,1 \%)$ \\
\hline Reoperáció vérzés miatt & $9(2,8 \%)$ & $5(1,9 \%)$ & $12(1,8 \%)$ \\
\hline Egyéb* & $1(0,3 \%)$ & $2(0,8 \%)$ & $4(0,6 \%)$ \\
\hline
\end{tabular}

*A beavatkozással nem közvetlenül összefüggő komplikációk.

**Az összehasonlítás az érmútőben végzett minimálisan invazív és a radiológián végzett percutan beavatkozások között történt; az alacsony esetszám miatt csak az összes szövődményt hasonlítottuk össze.

3. táblázat |Az alsó végtagi endovascularis beavatkozásokon átesett betegek egyéves utánkövetése (2012-2018)

\begin{tabular}{l|c|c|c|}
\hline \multirow{2}{*}{ Események } & \multicolumn{2}{|c|}{ Érsebészet } & Radiológia \\
\cline { 2 - 4 } & $\begin{array}{c}\text { Hibrid mútét } \\
266 \text { beteg }\end{array}$ & $\begin{array}{c}\text { Minimálisan invazív } \\
\text { beavatkozás } \\
219 \text { beteg }\end{array}$ & $\begin{array}{c}\text { Percutan intervenció } \\
562 \text { beteg }\end{array}$ \\
\hline Reoperáció/reintervenció & $51(19,2 \%)$ & $22(10 \%)$ & $33(5,9 \%)$ \\
\hline Kiegészító érmútét/intervenció & $11(4,1 \%)$ & $5(2,3 \%)$ & $28(5 \%)$ \\
\hline Major amputáció & $21(7,9 \%)$ & $10(4,6 \%)$ & $12(2,1 \%)$ \\
\hline Mortalitás & $15(5,6 \%)$ & $13(5,9 \%)$ & $22(3,9 \%)$ \\
\hline Nincs adat & $24(9 \%)$ & $35(16 \%)$ & 0,041 \\
\hline
\end{tabular}

*Az összehasonlítás az érmútőben végzett minimálisan invazív és a radiológián végzett percutan beavatkozások között történt. 
angiológiai, intervenciós radiológiai és érsebészeti munkacsoport között. A percutan intervenciók nagyobbrészt a radiológián történnek. Ehhez a betegek kiszűrése, diagnosztizálásuk megszervezése, az indikáció felállítása, az intézeti háttér biztosítása, az esetleges szövődmények ellátása, valamint az utánkövetés egyelőre jobbára a nagyobb ágy- és szakorvosszámú érsebészet feladatkörébe tartozik. Jelen gyakorlatunk szerint az érmütőben végzett perifériás endovascularis intervenciók többségét „emeletes” (több anatómiai régiót érintő) érbetegség miatti hibrid beavatkozások során végezzük.

A SZTE-n a vizsgált időszakban elvégzett alsó végtagi érintervenciós betegpopulációt vizsgálva a rizikófaktorok tekintetében az intervenciós radiológián kezelt betegek körében az ischaemiás szívbetegség és a hyperlipidaemia előfordulása gyakoribb volt. Az előbbi eredmény tükrözi is a betegszelekció hatékonyságát, ugyanis a jobb cardialis állapotú betegek gyakrabban kerültek érsebészeti mütétre. A másik fontosabb tényező, amelyet a terápia megválasztásakor súlyozottan figyelembe vettünk, az érelváltozás anatómiai lokalizációja és morfológiája volt. Az aortoiliacalis érrendszert érintő, kar felől könynyebben elérhető elváltozásokat nagyobb arányban irányítottuk a radiológiára, míg a femoropoplitealis régióra lokalizált, illetve a kiterjedtebb, esetleg több anatómiai régiót érintő laesiókat inkább érmútőben kezeltük nagyobb arányban.

A CLTI gyakorisága a kezelt betegek között az utóbbi években növekedést mutatott, aminek hátterében inkább a cruralis, illetve az „emeletes” lokalizáció jelenléte állhat. CLTI-t ritkán okoz izolált érbetegség, a diabeteses érbetegséget kivéve. Az ilyen, több anatómiai régiót érintő érelváltozásokat nagyobb arányban kezeltük hibrid módszerrel. Beteganyagunkban a CLTI gyakoriságának emelkedését okozhatja, hogy manapság a Fontaine I-II/a stádium mellett már II/b stádiumban is mind eredményesebben alkalmazható a konzervatív terápia bővülő eszköztára [4-7]. További magyarázat, hogy az endovascularis eszközök technikai fejlődése és hozzáférhetôségük javulása lehetővé tette a korábban inoperábilisnek minősített esetek egy részében végtagmentő céllal megkísérelt endovascularis beavatkozások elvégzését. Bár az egy ülésben, több érszakaszon végzett rekonstrukció feltételei mindkét intézetben adottak, ennek bizonyos esetekben a felhasználandó endovascularis eszközök ára miatt fellépő finanszírozási korlátok szabtak határt.

$\mathrm{Az}$ aortoiliacalis endovascularis intervenciók során a primer sztentelést részesítettük elönyben a PTA-val szemben. A módszer előnyeit több nemzetközi randomizált tanulmány is igazolta, továbbá az Európai Érsebészeti Társaságnak (European Society for Vascular Surgery - ESVS) a perifériás érbetegség kezelésére vonatkozó szakmai irányelve alapján is a primer sztentelés a választandó eljárás ezen terület atheroscleroticus laesióinak terápiájában $[7,14-16]$. A femoralis, illetve a femoropoplitealis régió kezelésében az ajánlások ugyancsak a primer sztentelést helyezik elötérbe [17, 18], a legfrissebb ESVS-irányelv azonban már javasolja a DEB-ek és DES-ek használatát is a femoropoplitealis érbetegségek kezelésére [7]. Klinikai vizsgálatok a hagyományos PTA-val szemben egyértelműen igazolták ezen gyógyszerkibocsátó eszközök előnyét a primer átjárhatóság tekintetében [19, 20]. Sajnálatos módon ezen technikai eszközöket finanszírozási okok miatt egyelöre nem áll módunkban rutinszerúen alkalmazni.

Az endovascularis beavatkozások után kettős thrombocytaaggregáció-gátló terápiát alkalmaztunk legalább 3 hónapon át. Az ESVS-irányelv ezt a perifériás sztentek alkalmazása esetére javasolja, a PTA-kra vonatkozóan nem fogalmaz meg ajánlást. Klinikai gyakorlatunkban mégis ezt az elvet követtük PTA-k esetén is, hiszen egyrészt a kétféle endovascularis kezelésen átesett betegek cardiovascularis kockázatában nincs különbség, másrészt a ballonos tágítást követő lokális thrombogenitasi viszonyok alacsonyabb voltára sem állnak rendelkezésre evidenciák. A sokszor elesett állapotú, idős, mobilitásukban tartósan korlátozott betegek thromboemboliás profilaxisa céljából maximum 30 napig tartó LMWH-profilaxist tartottunk szükségesnek. A kettős thrombocytaaggregáció-gátló kezelés, valamint az ezzel együtt alkalmazott LMWH-thrombosisprofilaxis nem növelte a 30 napon belüli vérzéses szövődmények előfordulását, alsó vagy felső gastrointestinalis vérzést sem észleltünk. A vérzés miatti reoperációk száma nem volt magasabb, mint más beteganyagon végzett érsebészeti beavatkozások kapcsán, azokat minden esetben a beavatkozás után néhány órán belül kellett végeznünk.

$\mathrm{Az}$ érsebészeti munkacsoport által végzett perifériás intervenciók száma fokozatosan emelkedett, 2016-ra ezen beavatkozások többségét (60\%) már érmútőben végeztük. Ezt követően a SZTE Sebészeti Klinikája az új helyére költözött, mely mindenképpen jelentős minőségi változást hozott mind az orvosok, mind a betegek életében. Sajnálatos módon azonban ezzel párhuzamosan az Érsebészeti Osztály ágyszáma 20\%-kal csökkent, így még fontosabbá vált a rövidebb ápolást igénylő (percutan) kezelések végzése. Az utóbbi két évben a perifériás intervenciók száma tovább emelkedett ugyan, de az érmútőben és a radiológián végzett beavatkozások aránya kiegyenlítődött.

Mind a rövid (30 napon belüli), mind a hosszú távú (egyéves) utánkövetés során az érsebészeti csoportban volt nagyobb a reoperációk, illetve a major amputációk aránya. Ezt az eredményt azonban több tényező is befolyásolta. A mútőben kezelt betegcsoportban gyakoribb volt a CLTI-t okozó „emeletes” érbetegség előfordulása, ami magyarázhatja a reoperációk és az amputációk magasabb arányú előfordulását. Ezzel szemben a radiológián kezelt csoportban a claudicatiós panaszt okozó, endovascularisan sikeresebben kezelhető szoliter iliacalis szúküuletek aránya volt nagyobb. A legszerényebb eredményekkel kecsegtető distalisabb régiók endovascularis kezelése (popliteocruralis) a helyi adottságok miatt pedig 
csaknem kizárólag az érsebészeten történt. Fontos azonban kiemelni, hogy ha csak a minimálisan invazív módon, érmútőben kezelt betegeket hasonlítjuk össze a radiológián kezelt betegekkel, a fenti különbségek csaknem minden tekintetben eltünnek.

Napjainkban a perifériás verőérbetegségben szenvedők aránya folyamatosan növekszik, ami több tényezőre vezethetô vissza. A háttérben a mindinkább öregedó korfával bíró jóléti társadalmakban a diabetes és a hypertonia incidenciájának emelkedése, az elhízás, a mozgásszegény életmód, a stressz és még számos egyéb egészségügyi és társadalmi ok állhat [21-23]. Hazánkban a dohányzó felnőttek aránya eleve nagyobb, mint az európai átlag, emellett sajnálatos módon az utóbbi években számuk még további növekedést mutatott, ami alapján a perifériás érbetegség előfordulásának növekedése is várható [24]. Ezzel párhuzamosan az ellátásban érintett érsebészek és intervenciós szakemberek száma nemhogy szaporodna, sajnálatos módon inkább csökkenni látszik, aminek oka döntően a 24 órában történő rendelkezésre állás, a mentálisan és fizikálisan megterhelő munkavégzés és a megbecsültség hiánya. Emiatt kevesen választják hivatásuknak a perifériás verőérbetegségben szenvedő betegek kezelését, sőt a könnyebb és jobban „kifizetőd”” élet reményében komoly méretű a pályaelhagyók száma is. Az ellátóhelyek jelentős részében a személyi és a tárgyi feltételek biztosítása mellett problémát jelent a költséges kezelések finanszírozása. A rendszer hiányosságai miatt a bajaikra megoldást kereső betegek bolyonganak az ellátórendszer bugyraiban, miközben az ebből fakadó időveszteség a kezelés sikerének esélyétől foszthatja meg őket. A probléma egyetlen hatékony és gazdaságos megoldását jelentheti az ellátórendszer újraszervezése, átláthatóvá tétele, centralizálása, aminek révén a meglévő anyagi és személyi feltételek maximális kiaknázása válna lehetővé. A betegutak tisztázása, egyértelmüvé tétele a rendszer működésének nélkülözhetetlen feltétele. Az elmúlt években észlelhető a kormányzat egészségügyi szakpolitikájának a fenti problémák megoldására irányuló törekvése. Ezt célozta az érsebészet hiányszakmává minősítése, ösztöndíj bevezetése, az érsebészeti fix díjak megemelése és a vascularis centrumok rendszerének kiépítésére vonatkozó koncepció kidolgozása is.

A fél- vagy akár másfél milliós lélekszámú régiók érbetegeinek teljes spektrumú perifériás vascularis ellátásáért felelős, a progresszivitás II. és III. szintjén kialakítandó központok hatékony múködésének fontos feltétele egyebek mellett az, hogy a hiányszakmák közt is kritikusan alacsony számú angiológus, vascularis intervenciós radiológus és érsebész szakorvos a teljes munkaidejét a perifériás érbetegek ellátására fordíthassa, s kapacitásaik számottevő részét ne az általános sebészeti, belgyógyászati vagy egyéb radiológiai teendők kössék le.

Az endovascularis beavatkozások számának növekedésével, illetve az ehhez szükséges képerősítők rutinszerú, akár napi használatával előtérbe került egy újabb szempont is, melyet a mútői személyzet fokozott sugárterhe- lése jelent $[25,26]$. A röntgen egészségkárosító hatásainak megelőzése érdekében alapvető a sugárveszélyes munkahelyen dolgozó munkavállalók sugárvédelmi képzése, rendszeres foglalkozás-egészségügyi alkalmassági vizsgálata és a biztonságos munkavégzés feltételeinek biztosítása, beleértve a megfelelő védőeszközöket. Ennek szellemében napjainkra már a hazai érsebész szakorvosok képzési curriculumának fontos részét képezi az emelt szintú sugárvédelmi tanfolyam és vizsga is. Ugyancsak a kérdés jelentőségét jelzi, hogy az ESVS sugárvédelemre vonatkozó irányelve publikálás előtt áll. Nemzetközi klinikai vizsgálat igazolta, hogy mobil DSA-készülék használatakor nagyobb sugárterhelésnek van kitéve a beteg - így az orvos is -, mint ha azt a beavatkozást dedikált vascularis hibrid mütőben, telepített készülékkel végezték volna [27]. Jelenleg Szegeden, de tudomásunk szerint más hazai központban sem áll az érsebészek rendelkezésére telepített DSA-eszközzel felszerelt, ambuláns betegellátásra alkalmas labor.

\section{Következtetés}

Eredményeink alapján megállapíthatjuk, hogy eredeti célunkat elérve, a radiológia intervenciós aktivitásának fenntartása mellett, növekvő számú pácienseink korszerú ellátásának biztosítására szakorvosaink megszerezték a szükséges katéteres jártasságot, melynek folyamatos fejlesztése azonban a legfontosabb jövőbeli célkitúzéseink egyike. Az endovascularis rekonstrukciós módszerek érsebészek által történő rutinszerü alkalmazásának jelentőségét a laparoszkópiáéhoz tartjuk hasonlatosnak, mely nélkül a hasi sebészet napjainkban már mindenki számára nyilvánvalóan elképzelhetetlen lenne.

Anyagi támogatás: A kutatómunka és a közlemény megírása anyagi támogatásban nem részesült.

Szerzôi munkamegosztás: T. T.: Adatgyüjtés, a cikk megírása, statisztikai elemzés, irodalomkutatás. P. Zs.: Szakmai vezető, adatellenőrzés, javítási javaslatok. M. G. és V. R.: Adatellenőrzés és az irodalmi háttér kutatása. N. A. és N. E.: A Radiológián végzett beavatkozások adatellenőrzése. A cikk végleges változatát valamennyi szerző elolvasta és jóváhagyta.

Érdekeltségek: A szerzőknek nincsenek érdekeltségeik.

\section{Irodalom}

[1] Treat-Jacobson D, McDermott MM, Beckman JA, et al. Implementation of supervised exercise therapy for patients with symptomatic peripheral artery disease: a science advisory from the American Heart Association. Circulation 2019; 140: e700-e710.

[2] Landi A, Jassó I. Peripheral arterial obliterative disease and physical activity. [Arteriosclerosis obliterans és fizikai tréning.] Orv Hetil. 2007; 148: 1059-1065. [Hungarian]

[3] Jansen SC, Hoorweg BB, Hoeks SE, et al. A systematic review and meta-analysis of the effects of supervised exercise therapy on 
modifiable cardiovascular risk factors in intermittent claudication. J Vasc Surg. 2019; 69: 1293-1308.e2.

[4] Bedenis R, Stewart M, Cleanthis M, et al. Cilostazol for intermittent claudication. Cochrane Database Syst. Rev. 2014; 2014(10): CD003748.

[5] Farkas K, Járai Z, Kolossváry E. Cilostazol is effective and safe option for the treatment of intermittent claudication. Results of the NOCLAUD study. [A cilostazol hatékony és biztonságos lehetőség a claudicatio intermittens kezelésére. A NOCLAUD vizsgálat eredményei.] Orv Hetil. 2017; 158: 123-128. [Hungarian]

[6] Farkas K, Kolossváry E, Járai Z. Cilostazol improves the quality of life and lower-limb functional capacity also in diabetic patients. [A cilostazol diabeteses betegekben is javítja az életminőséget és az alsó végtagi funkcionális kapacitást.] Orv Hetil. 2020; 161: 1637-1645. [Hungarian]

[7] Aboyans V, Ricco JB, Bartelink ME, et al. 2017 ESC guidelines on the diagnosis and treatment of peripheral arterial diseases, in collaboration with the European Society for Vascular Surgery (ESVS): Document covering atherosclerotic disease of extracranial carotid and vertebral, mesenteric, renal, upper and lower extremity arteries. Endorsed by: the European Stroke Organization (ESO). The Task Force for the Diagnosis and Treatment of Peripheral Arterial Diseases of the European Society of Cardiology (ESC) and of the European Society for Vascular Surgery (ESVS). Eur Heart J. 2018; 39: 763-816.

[8] Norgren L, Hiatt WR, Dormandy JA, et al. Inter-society consensus for the management of peripheral arterial disease (TASC II). J Vasc Surg. 2007; 45(Suppl): S5-S67.

[9] Farkas K, Mátyás L, Palásthy Zs, et al. Profession al guideline of the Hungarian Ministry of Human Capacities for the treatment of peripheral arterial diseases. [Az Emberi Erőforrások Minisztériuma szakmai irányelve a perifériás verőér megbetegedések ellátásáról.] EüK 2017; 3: 650-675. [Hungarian]

[10] Goodney PP, Beck AW, Nagle J, et al. National trends in lower extremity bypass surgery, endovascular interventions, and major amputation. J Vasc Surg. 2009; 50: 54-60.

[11] Anderson PL, Gelijns A, Moskowitz A, et al. Understanding trends in inpatient surgical volume: vascular interventions, 1980-2000. J Vasc Surg. 2004; 39: 1200-1208.

[12] Schneider PA. The future of vascular surgery. J Vasc Surg. 2015; 61: 1357-1365

[13] Veith FJ. A look at the future of vascular surgery. J Vasc Surg. 2016: 64: 885-890

[14] Bosiers M, Deloose K, Callaert J, et al. Bravissimo: 12-month results from a large scale prospective trial. J Cardiovasc Surg. 2013; 54: 235-253

[15] Ye W, Liu CW, Ricco JB, et al. Early and late outcomes of percutaneous treatment of TransAtlantic Inter-Society Consensus class C and D aorto-iliac lesions. J Vasc Surg. 2011; 53: 1728-1737.
[16] Goode SD, Cleveland TJ, Gaines PA. Randomized clinical trial of stents versus angioplasty for the treatment of iliac artery occlusions (STAG trial). Br J Surg. 2013; 100: 1148-1153.

[17] Laird JR, Katzen BT, Scheinert D, et al. Nitinol stent implantation vs. balloon angioplasty for lesions in the superficial femoral and proximal popliteal arteries of patients with claudication: three-year follow-up from the RESILIENT randomized trial. J Endovasc Ther. 2012; 19: 1-9.

[18] Schillinger M, Sabeti S, Dick P, et al. Sustained benefit at 2 years of primary femoropopliteal stenting compared with balloon angioplasty with optional stenting. Circulation 2007; 115: 27452749 .

[19] Liistro F, Grotti S, Porto I, et al. Drug eluting balloon in peripheral intervention for the superficial femoral artery: the DEBATESFA randomized trial (drug eluting balloon in peripheral intervention for the superficial femoral artery). JACC Cardiovasc Interv. 2013; 6: 1295-1302.

[20] Tepe G, Laird J, Schneider P, et al. Drug-coated balloon versus standard percutaneous transluminal angioplasty for the treatment of superficial femoral and popliteal peripheral artery disease: 12 -month results from the IN.PACT SFA randomized trial. Circulation 2015; 131: 495-502.

[21] Chen L, Magliano DJ, Zimmet PZ. The worldwide epidemiology of type 2 diabetes mellitus - present and future perspectives. Nat Rev Endocrinol. 2012; 8: 228-236.

[22] James PT. Obesity: the worldwide epidemic. Clin Dermatol. 2004; 22: 276-280.

[23] Salem H, Hasan DM, Eameash A, et al. Worldwide prevalence of hypertension: a pooled meta-analysis of 1670 studies in 71 countries with 29.5 million participants. J Am Coll Cardiol. 2018; 71(11_Suppl): A1819.

[24] Kékes E, Barna I, Daiki T, et al. The prevalence of smoking and gender differences according to the data of the national health screening program in 2010-2018 in Hungary. [Nemi különbségek a dohányzás gyakoriságában hazánkban 2010 és 2018 között.] Orv Hetil. 2019; 160: 2047-2053. [Hungarian]

[25] Walsh SR, Cousins C, Tang TY, et al. Ionizing radiation in endovascular interventions. J Endovasc Ther. 2008; 15: 680-687.

[26] Kim JB, Lee J, Prk K. Radiation hazards to vascular surgeon and scrub nurse in mobile fluoroscopy equipped hybrid vascular room. Ann Surg Treat Res. 2017; 92: 156-163.

[27] Rehman ZU, Choksy S, Howard A, et al. Comparison of patient radiation dose and contrast use during EVAR in a dedicated hybrid vascular OR and mobile imaging. Ann Vasc Surg. 2019; 61: $278-283$.

(Takács Tibor dr., Szeged, Semmelweis u. 8., 6720 e-mail: drtakacs77@gmail.com)

A cikk a Creative Commons Attribution 4.0 International License (https://creativecommons.org/licenses/by/4.0/) feltételei szerint publikált Open Access közlemény melynek szellemében a cikk bármilyen médiumban szabadon felhasználható, megosztható és újraközölhetö, feltéve, hogy az eredeti szerző és a közlés helye, illetve a CC License linkje és az esetlegesen végrehajtott módositások feltüntetésre kerülnek. (SID_1) 